\title{
The Flat feet Increased The Postural Instability on The Elderly in Nursing Home
}

\author{
Fathia Larasati, Titi Moertolo, Kirana Anggraeni \\ Faculty of Medicine, University of Trisakti
}

\begin{abstract}
Introduction: Flat feet or flatfeet are the postures that have a low medial longitudinal arch. The prevalence of Flat feet was $10-25 \%$ of adults population. The lower feet arch might have an impact on body sway have during standing posture. Furthermore, increasing of the postural sway could have the higher risk of fall in elderly, that has a prevalence of $30-50 \%$. The aim study to find the correlation between the Flat feet posture with postural stability, to prevent the risk of fall in the elderly.
\end{abstract}

Method: This design was observational cross-sectional study. The study conducted in the elderly nursing home. The posture was examined by ink feet print on white paper. The Tinetti Balance Assessment assessed the postural stability.

Result: The subjects were 84 elderly, mostly were $60-74$ years old, and $46(54,8 \%)$ were female. The most prevalence of the postural stability was the low risk of fall (59,5\%). The frequency of Flat feet was $26(31 \%)$. There was a relationship between Flat feet with postural stability in elderly $(p=0,020)$.

Conclusion: There was a correlation between the Flat feet and the postural stability on elderly in the nursing home.

Keywords: Flat feet, postural stability, elderly

\section{Correspondence Detail:}

\section{Fathia Larasati}

Email : fathialrst@gmail.com 


\section{BACKGROUND}

The feet is the most distal segment of the lower extremity and a relatively small for the support base to maintain the body balance. ${ }^{1}$ The bones of the feet arranged in two arches, longitudinal and transverse that are held by ligaments and tendons. The arches enable the feet to support the weight of the body, provide an ideal distribution of body weight and as the leverage while walking. ${ }^{2}$ The role of the feet arches is to support body weight, maintain the dynamic postural control, and provide body balance around the gravity axis. ${ }^{3}$ Therefore, lowering the feet arch may reduce the balanced. The posture with lowering the longitudinal arches called by the Flat feet. ${ }^{4}$ The prevalence was $10-25 \% .{ }^{5}$ There were several etiologies as the caused, such as excessive body weight, abnormalities of body posture, weakened of the connective tissues, and genetic predisposition ${ }^{2}$ The Flat feet deformity affects the biomechanics of the feet, alignment of the ankle, and alignment of the hip-knee joints, ${ }^{4}$ and as a result is an abnormality of biomechanic chain on the feetknee-hip joint, that may decrease the stability of posture. ${ }^{5}$ The Recent study shows that there is a relation between deformation of the feet arch and the body sway while standing in a static posture. ${ }^{6}$ Increasing of the postural sway in elderly may higher the risk of falling in elderly. The earlier studies have found that there was a correlation between feet arch structure with postural stability on elderly, ${ }^{7}$ and there was also a correlation between feet type and posture on elderly ${ }^{8}$. Elderly who has Flat feet was increasing the center of pressure (CoP) sway, that was mean the arch structure of the feet has an essential role in postural control. ${ }^{7}$ There was another factor that affected the posture stability and the risk of fall, such as the physical activity. ${ }^{9}$ The relationship between low arch feet with postural stability and balance have detected since adult age ${ }^{10}$ and the childhood. ${ }^{11}$ Identification of the feet problem expected has an impact on improved the posture stability. There was a well-known method to correct the low arch feet by feet orthoses that have proven to improved the lower extremity function ${ }^{12}$ and might be improved the postural stability as well.

Approximately $28 \%$ to $35 \%$ of people aged 65 and over fall each year. The following injuries of falls are considered a significant public health problem. Falls account for more than half of injury-related hospitalizations among old people. ${ }^{13}$ Fall is a severe and significant issue problem facing the elderly. The prevention of falls that contribute to preventing disability, mainly in older adults.$^{14}$

Based on described above, the Flat feet posture was one of the risks of fall in the elderly. The presence of flat feet diminishes the quality of life and feet function. ${ }^{15}$ In clinical practice flat feet may be diagnosed through different procedures, such as clinical diagnosis, radiological study ${ }^{16}$ and footprint analysis ${ }^{17}$. The suitable for diagnosing flatfeet in adults, especially Clarke's angle, which is highly accurate for flatfeet diagnosis ${ }^{18}$.The flat feet has associated with family history, the use of footwear in infancy, obesity and public residence ${ }^{19}$, and it has also associated with age ${ }^{20}$.

The of study aimed to found the relationship between flat feet posture with the postural stability (postural sway) in the elderly who lived in the nursing home. The information from this study can be used to prevent fall on the elderly. 


\section{METHODS}

The design study was cross-sectional observational analytic to find the relationship between the Flat feet posture with the postural stability. The samples were elderly who lived in nursing home Panti Social Tresna Werdha Budi Mulia 2 Cengkareng, selected by random sampling. The inclusion criteria in this study were aged over 60 years, can be invited to communicate well, and able to walk. Assessment of the posture to found the Flat feet was by ink feet print on the white paper. Evaluation of the posture stability was Tinetti Balance Assessment. Data analysis uses SPSS version 20.0 for Windows

\section{RESULTS}

The subjects were 84 elderly with the characteristics in Table 1

Table 1 study subjects characteristics

\begin{tabular}{|c|c|c|}
\hline \multirow{2}{*}{ Variable } & \multicolumn{2}{|c|}{ Frequency } \\
\hline & Total $(n=84)$ & Percent (\%) \\
\hline \multicolumn{3}{|l|}{ Gender } \\
\hline Male & 46 & 54,8 \\
\hline Female & 38 & 45,2 \\
\hline \multicolumn{3}{|l|}{ Age } \\
\hline 60-74-year-old & 70 & 83,3 \\
\hline 75-90-year-old & 12 & 14,3 \\
\hline$\geq 90$-year-old & 2 & 2,4 \\
\hline \multicolumn{3}{|l|}{ Postural Stability (Tinetti score) } \\
\hline Low Risk of Fall ( $\geq 24)$ & 50 & 59,5 \\
\hline Moderate Risk of Fall (19-23) & 19 & 22,6 \\
\hline High Risk of Fall $(\leq 18)$ & 17 & 17,9 \\
\hline Mean of the Tinetti score & 23,39 & \\
\hline Feet Shape & & \\
\hline Normal & 58 & 69,0 \\
\hline Flat feet & 26 & 31,0 \\
\hline
\end{tabular}

In univariate analysis, the results of the study showed that out of 84 respondents, the study sample was dominated by male respondents as many as 46 (54.8\%). The highest the age group was $60-74$ years on 70 $(83.3 \%)$ subjects. 
The Tinetti Balance Assessment Tool was used to determine the postural stability. The result was the most subjects had a low risk of falls (score $\geq 24$ ), and the mean of Tinetti test score was 23,39.

The examination of posture has revealed that most of subjects $39(46 \%)$ had normal posture.

The relationship between Flat feet and postural stability

Table 3 The correlation between the Flat feet and the Tinetti test Score

\begin{tabular}{|c|c|c|c|c|c|}
\hline \multirow[b]{2}{*}{ Variable } & \multicolumn{3}{|c|}{ Postural Stability } & \multirow[b]{2}{*}{ Total } & \multirow[b]{2}{*}{$\mathbf{p}$} \\
\hline & $\begin{array}{c}\text { Low Risk of Fall } \\
\geq 24\end{array}$ & $\begin{array}{c}\text { Moderate Risk of Fall } \\
19-23\end{array}$ & $\begin{array}{c}\text { High Risk of Fall } \\
\leq 18\end{array}$ & & \\
\hline Normal & 39 & 13 & 6 & 58 & \\
\hline Flat feet & 11 & 6 & 9 & 26 & \\
\hline Total & 50 & 19 & 15 & 84 & $0.020^{*}$ \\
\hline
\end{tabular}

*chi-square

The data in Table 2 has shown that 39 of the elderly who had standard feet shape have a low risk of fall, in contrast on the high risk of fall group has more of the Flat feet subjects $(p=0.020)$

\section{DISCUSSION}

The study conducted on 84 elderly subjects who lived in Government nursing home. All of the subjects were able to walk independently, and do not have any injury or inflammation on the lower extremities. The feet posture was assessed by ink feet print, and calculated by Clarke's angle method. The postural sway has examined by Tinetti balance score.

The study has shown that $31 \%$ of the subjects have Flat feet, that was slightly higher than the earlier studies have found was $10-25 \%$ of the population. .,6,16-19 $^{2}$

A study by Kyunggock Yi and Namhee have found the normal feet prevalence was then the Flat feet posture in the elderly subjects. ${ }^{9}$

Postural sway has evaluated by Tinetti Balance Assessment Tool has the results was the low risk of fall that has Tinetti score $\geq 24$ has the highest frequency $(59,5 \%)$, followed by the moderate and high risk of fall were $22,6 \%$ and $17,9 \%$ respectively. The results of this study have supported the study in Jaten Klaten, that were $45 \%$ of the 75 subjects had a low risk of fall. ${ }^{8}$ 
Although most of the subjects have a low risk of fall, interestingly there was the correlation between the feet posture and the postural sway, that has tested by the Chi-square $(\mathrm{p}=0.020)$. The distribution of data has shown that there was the highest number of the standard feet in the low risk of fall group, in contrast in the high risk of fall has the higher number of subjects with the Flat feet posture. This result study has agreed with the previous studies that found a relationship between Flat feet and postural stability in the elderly. ${ }^{8,9}$ The correlation between Flat feet and postural stability has found on the adolescence population that revealed from the study by Fayiz et al.${ }^{10}$, and on the children from the study by Kadek AA et al. ${ }^{11}$.

\section{CONCLUSION}

This study has revealed that $31 \%$ of the subjects have flat feet posture, while $59,5 \%$ of the subjects have a low risk of fall. There was the correlation between the flat feet with the postural sway by Tinetti balance score. From this study may be concluded that the elderly subject who has flat feet posture has a higher risk of fall.

It is necessary to recommend the correction of flat feet in the elderly to prevent the fall.

\section{ACKNOWLEDGMENT}

Highest appreciation to all Subjects from the Panti Social Tresna Werdha-2 who have participated in this study, to all management, all of the staff and caregiver of the nursing home that has cooperated and facilitation this study. The last but not the least is to all the Lectures from Faculty of Medicine, University of Trisakti, Jakarta.

\section{REFERENCES}

1. Karen PC, Brunet ME, Bruce MG, Shultz JS. Effects of Pronated and Supinated Postures on Static and Dynamic Postural Stability. Journal of Athletic Training. 2005; 40: 41-46

2. Tortora B. Principles of Anatomy and Physiology 12th Ed. 2009 John Wiley\&Sons

3. Clifford AM, Holder-Powell H. Postural control in healthy individuals. Clin Biomech (Bristol, Avon). 2010; 25: 546-51.

4. Razieh T, Karimi TM, Behnaz S, Francis F. Evaluation of Standing Stability in Individuals With Flatfeet. Orthotics and Prosthetics, Rehabilitation Faculty of Isfahan University of Medical Sciences. 2014. Available at: https://doi.org/10.1177/1938640014557075

5. Rachmawati MR, Tulaar ABM, Immanuel S, et al. Correcting of pronated feet reduce skeletal muscle injury in young women with biomechanical abnormalities. Anatomy \& Cell Biology. 2016;49(1):1520. doi:10.5115/acb.2016.49.1.15. 
6. SN Periya, J Alagesan. Prevalence and incidence of flat feet among Middle East dan Asian Population: An Overview. Int J Pharm Sci Res. 2017;4(7):8-9

7. Anzai E. Effects of Feet Arch Structure on Postural Stability. 2014. Japan: Ochanomizu University.

8. Kyungock Yi, Namhee Kim. Correlation between feet type and posture for the elderly. J Feet Ankle Res 2014. Available at: https://doi.org/10.1186/1757-1146-7-S1-A89

9. Firda DA. Hubungan Antara aktivitas fisik dengan resiko jatuh pada lanjut usia di desa jaten kecamatan juwiring klaten. Fakultas Ilmu Kesehatan Universitas Muhammadiya Surakarta. Surakarta; 2017

10. Fayiz FE, Anees SG. Effect of flexible Flat feet on postural stability in adolescent females. IJSR 2012; 3: $653-654$

11. Kadek AA, Nyoman IA, Wayan IS. Hubungan flat feet dengan keseimbangan statis dan dinamis pada anak sekolah dasar negeri four tonja kota Denpasar. Majalah Ilmiah Fisioterapi Indonesia; 3: 23

12. Rachmawati MR, Tulaar A, Mansyur M, Idris FH, Ismail, Haryadi RD. Feet orthoses improve kinematic measurement in young women with biomechanical abnormality. Univ Med. 2013;32:187-96

13. Almegbel FY, Alotaibi IM, Alhusain FA, et al. Period prevalence, risk factors and resulting injuries of falling among the Saudi elderly living in Riyadh, Saudi Arabia: a cross-sectional study. BMJ Open. 2018;8(1):e019063. doi:10.1136/bmjopen-2017-019063.

14. Dionyssiotis Y. Analyzing the problem of falls among older people. International Journal of General Medicine. 2012;5:805-813. doi:10.2147/IJGM.S32651.

15. Pita-Fernandez S, Gonzalez-Martin C, Alonso-Tajes F, et al. Flat feet in a Random Population and its Impact on Quality of Life and Functionality. Journal of Clinical and Diagnostic Research : JCDR. 2017;11(4): LC22-LC27. doi:10.7860/JCDR/2017/24362.9697.

16. Murley GS, Menz HB, Landorf KB. A protocol for classifying normal- and flat-arched posture for research studies using clinical and radiographic measurements... J Feet Ankle Res. 2009; 4(2):22

17. Queen RM, Mall NA, Hardaker WM, Nunley JA Describing the medial longitudinal arch using footprint indices and a clinical grading system.Feet Ankle Int. 2007; 28(4):456-62

18. Pita-Fernández S, González-Martín C, Seoane-Pillado T, López-Calviño B, Pértega-Díaz S, GilGuillén V. Validity of Footprint Analysis to Determine Flatfeet Using Clinical Diagnosis as the Gold Standard in a Random Sample Aged 40 Years and Older. Journal of Epidemiology. 2015;25(2):148154. doi:10.2188/jea.JE20140082.

19. Abdel-Fattah MM, Hassanin MM, Felembane FA, Nassaane MT. Flat feet among Saudi Arabian army recruits: prevalence and risk factors. East Mediterr Health J. 2006; 12(1-2):211-7.

20. Abolarin TO, Aiyegbusi AI, Tella BA, Akinbo SR, Nig Q. Relationship between selected anthropometric variables and prevalence of flat feet among urban and rural school children in south west Nigeria. $\mathrm{J}$ Hosp Med. 2011; 21(2):135-40. 


\section{Information and Instructions to the authors - Indonesian Journal of Physical Medicine and Rehabilitation}

\section{Preparing for submission}

Submission of a manuscript is held to imply that it has not been published previously and is not otherwise submitted for publication, except as an abstract (which in that case has to be stated).

\begin{abstract}
Authorship
All persons designated as authors must participate sufficiently in the work to take public responsibility in its contents. A statement on each author's contribution must be described in the accompanying letter if there are five or more authors.
\end{abstract}

\section{Length and number of copies}

Articles should not exceed 10 printed pages singlespaced, max. 5000 words. Submission can be made online to pmr.journal.ina@gmail.com. (A complete copy of the manuscript, including tables and figures, accompanied by a submission letter can also be sent via ordinary mail if the interest option is not possible. In that case, please also submit the soft copy with the complete manuscript). For further information please contact the Editorial Office.

\section{Language}

All papers should be written in English. It is essential that the language is irreproachable.

\section{Ethics and consent}

When reporting studies on human subjects, indicate whether the procedures have been approved by the ethics committee. Do not use patients' names, initials, or hospital numbers, especially in the illustrative material. Identifying information should not be published in written descriptions, photographs, and pedigrees unless the information is essential for scientific purposes and the patient (or parent or guardian) permits written informed consent for publication. Informed consent for this purpose requires that the patient be shown the manuscript to be published.

\section{Arrangement of manuscript}

Manuscripts should be typewritten, single-spaced throughout, on one side of the paper, with ordinary margins. Paper should normally be divided into Title page, Abstract, Introduction (including clear statement of the aim of the study), Methods, Results, Discussion, Conclusion, and References.

\section{Title Page}

A separate title page is necessary and should consists:

a) The title of the article (should not contain abbreviation and the total number of words should not exceed 14 words),

b) Names of the authors,

c) The institutions of origin,

d) A short title, and the corresponding author's name, address, telefax number and email.

\section{Abstract \\ Indonesian Journal of Physical Medicine and Rehabilitation requires structures abstracts for all original articles. The following headlines should be used when appropriate: Introduction should contain a clear aim of the study, Methods and Materials, Result, and Conclusions. The total number of words should not exceed 200. A list of from 3-8 keywords suitable for indexing terms should be typed at the bottom of the abstract page. \\ Below the abstract: Title of journal; principal author's complete address, including e-mail.}

\section{References}

Should be numbered consecutively in the order in which they are first mentioned in the text. The style of references must follow the most updated Vancouver system.

\section{Tables and figures}

Tables are to be numbered consecutively with roman numerals. Each table should be typed on a separate sheet and should have a descriptive heading which is self-explanatory.

All illustrations should be considered as figures. Each graph, drawing, or photograph should be numbered in sequence with Arabic numerals. All figures should have legends, listed on a separate sheet. Each figure should be indentified by the name of the journal, the author's name, and the figure number. Line drawing and lettering should be large enough to sustain photo-reduction.

\section{Address for Editorial Office}

Indonesian Journal of Physical Medicine and Rehabilitation

Sekretariat PB PERDOSRI

Jalan Cakalang Raya No. 28A

Jakarta Timur

Phone : +62 2147866390

Email :pmr.journal.ina@gmail.com 